\title{
Holdfasts of adult kelp Ecklonia maxima provide refuges from grazing for recruitment of juvenile kelps
}

\author{
R. J. Anderson ${ }^{1, *}$, P. Carrick ${ }^{2}$, G. J. Levitt ${ }^{1}$, A. Share ${ }^{1}$ \\ ${ }^{1}$ Sea Fisheries Research Institute, Private Bag X2, Roggebaai, 8012 Cape Town, South Africa \\ ${ }^{2}$ Department of Botany, University of Cape Town, Rondebosch 7700 , South Africa
}

\begin{abstract}
The distribution of young sporophytes (up to $0.25 \mathrm{~m}$ stipe length) of the kelp Ecklonia maxima, on various substrata, at depths of 2.5 to $5.0 \mathrm{~m}$, was studied at 8 sites on the southwest coast of South Africa. The most common substratum available was rock (bare or covered with encrusting coralline algae), followed by kelp holdfasts, and the ascidian Pyura stolonifera at some sites. A disproportionately high ratio (relative to the available substrata) of young sporophytes grew on the holdfasts of mature kelps at most sites, but particularly where high densities of benthic invertebrate grazers were present (mainly the urchin Parechinus angulosus, also abalone Haliotis midae, limpets Patella spp. and gastropods Turbo spp. and Oxystele spp.). Jacobs' index of electivity was used an indicator of 'preference for' (interpreted as indicating survival on) the substratum type. This showed a statistically significant 'negative selection' of rock as a substratum at sites where grazers were numerous. The ratios of young sporophytes on holdfasts/young sporophytes on rock were directly proportional to grazer densities when sites were compared $(r=-0.90, p=0.002)$, supporting the hypothesis that mature holdfasts are an important refuge for recruitment of E. maxima sporophytes. There was an inverse relationship between percentage cover of understorey algae and grazer densities ( $\mathrm{r}=0.92, p=0.001)$. In general, sites east of Cape Point (west coast/south coast transition zone) have far more grazers and reduced understorey algal biomasses compared to west coast sites. There thus appear to be fundamental differences in some of the major ecological processes in kelp beds in these 2 areas, with important implications for commercial kelp harvesting.
\end{abstract}

KEY WORDS: Kelp - Recruitment - Herbivores Predation - Sea urchin - Ecklonia maxima - Parechinus angulosus

\section{INTRODUCTION}

Recruitment success is probably the most fundamental process determining the distribution and community structure of benthic marme organisms. Recruitment of kelps has been shown to depend on a variety of interacting factors. In California, Macrocystis pyrifera sporophytes recruited along large stretches of coast when the interrelated conditions of temperature, nutrients, light and water motion were optimal (Deysher $\&$ Dean 1986). Within such 'recruitment windows' these authors considered that biological interactions increased the variance in recruitment, but not the large-scale temporal and spatial patterns. Biological

•E-mail: anderson@botzoo.uct.ac.za interactions affecting recruitment in kelp systems include inter- and intraspecific competition (Kennelly 1987) and widespread examples of herbivory, where recruits may be completely eradicated, producing 'barrens' (see for example Chapman \& Johnson 1990), or else reduced and spatially limited (Fletcher 1987, Santelices 1990, Dayton et al. 1992, Camus 1994).

Southern African kelp beds extend from just west of Cape Agulhas (the southern tip of Africa), around the southwest coast as far as northern Namibia. In the south the dominant species in shallow water $(0$ to $8 \mathrm{~m})$ is Ecklonia maxima (Osbeck) Papenfuss. There is a sub-canopy of Laminaria pallida Greville ex J. Agardh which becomes the dominant species at depths from about 8 to $20 \mathrm{~m}$ and replaces E. maxima in inshore beds on the northern west coast and in Namibia. The dominant organisms in kelp beds of the southern west 
coast of South Africa (see Fig 1) have been fairly well studied from the point of view of biomass (e.g. Velimirov et al. 1977. Field et al. 1980) and energy flow (see review by Newell et al. 1982), and the major trophic pathways identified. The most abundant benthic herbivores in 6 large beds surveyed by Field et al. (1980) were the urchin Parechinus angulosus, followed by the abalone Haliotis midae and the gastropod Turbo cidaris. Energy-flow models indicate that herbivores comprise a relatively small trophic group (Newell et al. 1982). However, interactions between grazers and primary producers may move beyond the 'simple acquisition of energy' (Fletcher 1987) and into the realm of complex structuring processes, which are almost unstudied in these kelp beds.

The above energy-flow models were based on kelp beds west of Cape Point, as typified by the system at Oudekraal, on the west coast of the Cape Peninsula. There is a further $200 \mathrm{~km}$ of coast between Cape Point and Cape Agulhas which also supports extensive kelp beds, but here the understorey (and intertidal) seaweed flora is intermediate between those of the cool west coast and the warmer south coast. This is termed the south/west coast transi-

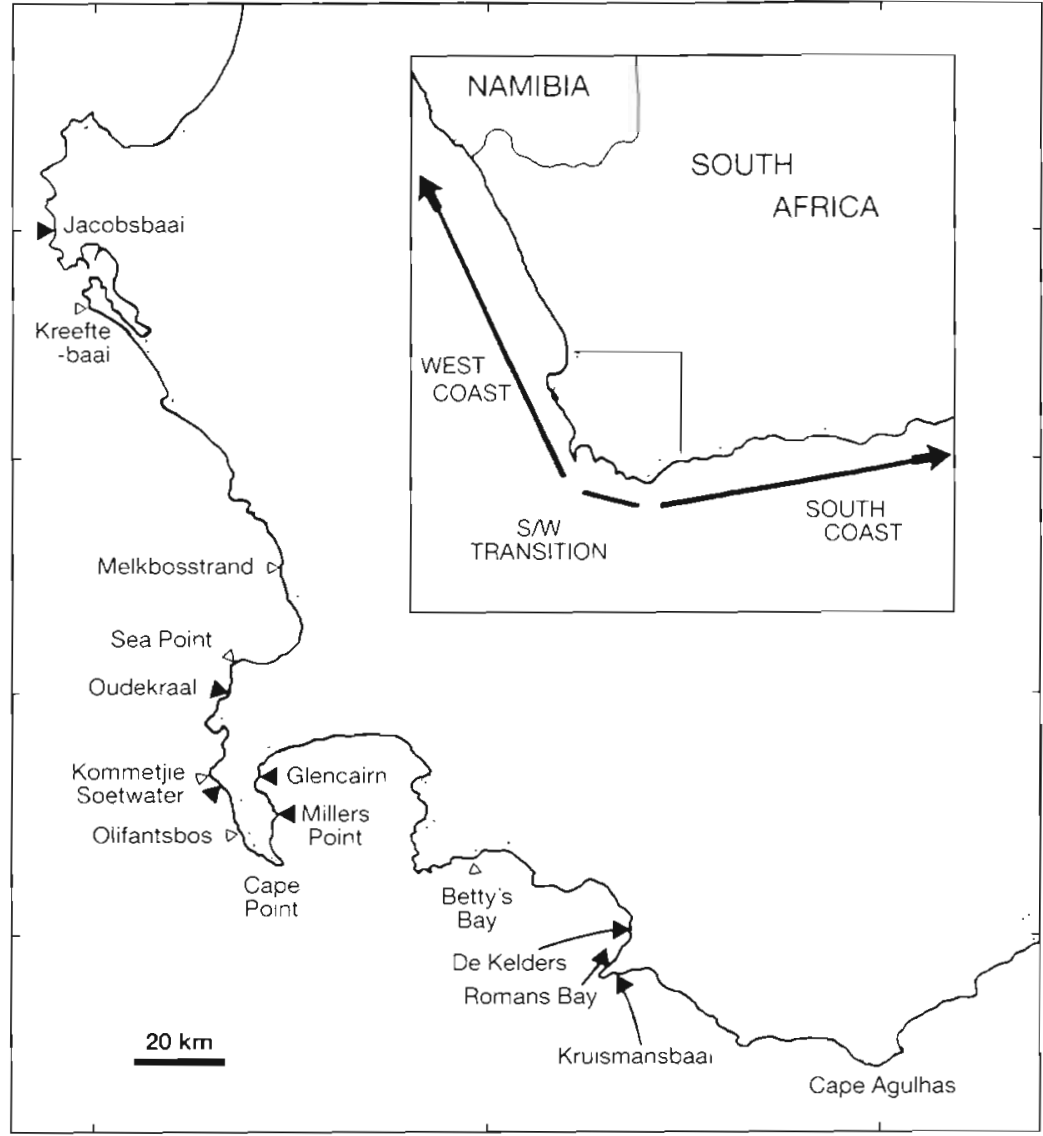

Fig. 1. The southwestern coast of South Africa, with inset showing location and marine phytogeographical areas (after Boiton 1986). (4) Sampling sites for this study, ( $\Delta$ ) sites sampled by Field et al. (1980), whose data are used here tion zone by Bolton (1986), who studied the phytogeography of the macroalgae. However, we believe that the west coast and transition zone kelp understorey communities also differ from each other in structure and appearance. In the shallow water of west coast kelp beds ( 1 to $8 \mathrm{~m}$ below MLWS, mean low water spring tide), dense red algae cover most of the substratum. In the transition zone there are numerous benthic grazers (especially urchins), extensive pavements of encrusting coralline red algae, and reduced cover of foliose seaweeds.

Ecklonia maxima dominates the inshore areas of both west coast and transition zone kelp beds. This species has been harvested commercially at Soetwater (Fig. 1) for many years, for the production of an agricultural growth stimulant. In harvested areas, divers cut out all plants with stipes longer than $0.5 \mathrm{~m}$, but recruitment into cut lanes is rapid at this west coast site. A dense bottom cover of small sporophytes appears within a year, and a surface canopy is re-established within 2 to 3 yr (Anderson et al. 1989). In the transition zone, at Romans Bay and Kruismansbaai (Fig. 1), recovery of harvested kelp beds is slower, and cleared lanes were
Iargely still visible more than 3 yr later. These areas support numerous urchins, abalone, and Turbo cidaris. During the course of harvesting experiments, we observed that when benthic grazers are numerous, most juvenile kelp sporophytes occur on the holdfasts of adults, and few on rock. We therefore set out to test the hypothesis that the holdfasts of adult kelp plants provide an important refuge for recruitment of juvenile Ecklonia maxima sporophytes when benthic grazers are abundant. In addition, we examined our own and published information to see whether there are differences between the west coast and south/west coast transition zone, with respect to biomass of benthic grazers and understorey macroalgae, which might indicate geographical differences in processes.

\section{MATERIALS AND METHODS}

Study sites. Eight sites were selected to represent typical kelp beds on the southwestern coast of South Africa (Fig. 1). Three sites (Soetwater, Oudekraal and 
Jacobsbaai) are typical of the cool west coast (Benguela) phytogeographical region (sensu Bolton 1986). Five sites were placed in the somewhat warmer south/west coast transition zone (sensu Bolton 1986). De Kelders, Romans Bay and Kruismansbaai lie around the Danger Point peninsula, where temperatures are slightly warmer than the west coast and typical of the transition zone. The 2 remaining sites (Millers Point and Glencairn) are in False Bay, which lies in the transition zone but where summer temperatures are higher because of solar heating of entrained water Details of phytogeography and temperatures are provided by Bolton (1986). Data from Field et al. (1980) are referred to, from the 5 west coast and 1 transition zone site which they surveyed (Fig. 1).

Sampling. Diving was done over a 4 mo period from May to August 1994. All sampling employed SCUBA, and was limited to between 2 and $4.5 \mathrm{~m}$ below MLWS to reduce biotic differences due to depth. Only approximately horizontal surfaces with kelp plants were sampled. Between 10 and 20 replicate quadrats, each of $1 \mathrm{~m}^{2}$, were placed haphazardly at each site. Within each quadrat all benthic macroinvertebrates were identified and counted. No attempt was made to count meso- or microherbivores (e.g. small crustaceans). The percentage cover of the following species or groups of organisms was visually estimated: rock (including encrusting coralline algae because these could often not be clearly differentiated when crusts were thin or patchy), Pyura stolonifera (Ascidiacea), understorey algae, holdfasts of Ecklonia maxima and Laminaria pallida, and sponges (Porifera). The stipe length of each kelp plant was measured, and its substratum recorded. The E. maxima and L. pallida sporophytes were initially separated into 8 size classes according to stipe length, but only 2 classes were retained for analysis: up to $0.25 \mathrm{~m}$ and larger than $0.25 \mathrm{~m}$. This was because it was difficult to determine the substratum that plants larger than about $0.5 \mathrm{~m}$ were in fact growing on. Larger holdfasts were often fused together, and it was impossible to tell whether holdfasts may have grown off the initial site of recruitment and onto the rock. Laminaria pallida data were omitted from the analysis because this species occurred only in the 3 west coast sites, and even there was rare in this shallow water.

Analysis. Three broad substratum types were identified as common kelp recruitment sites: rock (including encrusting-coralline covered rock), holdfasts of larger kelps and tests of Pyura stolonifera. From percentage cover estimates, the mean proportion of each type of substratum at each site was calculated, as well as the mean number of young sporophytes occurring on each substratum type. To assess relative recruitment on the 3 main substrata, Jacobs' index of electivity $(Q)$ was calculated, as follows:

$$
Q=\log r(1-p) / p(1-r)
$$

(Jacobs 1974) where $p=$ fraction of given substratum type, and $r=$ fraction of young sporophytes on that substratum.

Although we recognise that recruits may not be 'selecting' substrata, this index, which has been used in various studies (e.g. habitat selection in fish; Wilkins \& Myers 1992), provides a useful measure of relative 'preference' for substrata which is interpreted here as an index of relative recruitment success of young sporophytes. Jacobs' indices were compared statistically using a 1-way ANOVA and Tukey HSD test (see Table 1). Because Jacobs' indices can be negative, all values were made positive by increasing the lowest value to a positive integer, and all others by a corresponding amount. The final results were then readjusted.

The mean densities of benthic grazers at each site were calculated. The ratio of young sporophytes on holdfasts/young sporophytes on rock and the mean percentage cover of understorey algae at the 8 sites were separately regressed against mean density of grazers. To determine whether there were geographical patterns in the biomass of algae and benthic grazers on west coast and transition zone shores, we reanalysed the following data from the appendices of Field et al. (1980), for depths from 0 to $10 \mathrm{~m}$ : total biomass of understorey algae, total biomass of kelps, biomass of Parechinus angulosus, Turbo spp., Haliotis midae, Patella spp. and total biomass of these 4 grazers. We converted their data from energy units to mass using the conversion values they provide. Further biomass data were obtained from a current study on the effects of kelp harvesting at Romans Bay and Kruismansbaai (G. J. Levitt unpubl.). Here several hundred $0.25 \mathrm{~m}^{2}$ quadrats were placed in a series of transects from about 1.5 to $8 \mathrm{~m}$ depth, and all macroscopic benthic organisms collected and weighed. Data on benthic grazers and understorey algae are combined with re-calculations of data from Field et al. (1980) to examine the relationship between biomass of understorey algae and biomass of benthic grazers. Using the statistical package 'Fig P', the best fit was found using a logistic sigmoid curve.

\section{RESULTS}

At the 5 sites in the transition zone east of Cape Point (Millers Point, Glencairn, De Kelders, Romans Bay and Kruismansbaai), most of the available substratum (Fig. 2) was rock (bare rock and rock covered by encrusting corallines). Holdfasts of larger kelps were the next most abundant substratum, with Pyura stolonifera abundant at Glencairn. The 3 west coast sites 


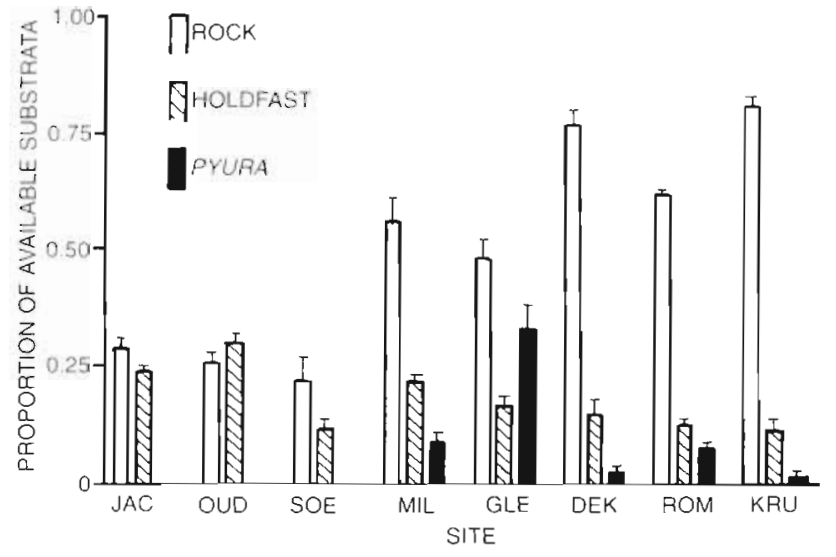

Fig. 2. Proportion of available substratum per area of sea bed at the 8 study sites, west (left) to east (right). JAC: Jacobsbaai; OUD: Oudekraal; SOE: Soetwater; MIL: Millers Point; GLE Glencairn; DEK: De Kelders; ROM: Romans Bay; KRU: Kruismansbaai. Vertical lines show standard errors of means

had considerably less rock, but similar holdfast abundance. There was no $P$. stolonifera at the west coast sites sampled, and the remainder of the bottom cover comprised dense understorey algae and sponges, which are not shown here as they are insignificant as a substratum for kelp recruitment.

At all sites except Soetwater, more juvenile Ecklonia maxima were attached to adult holdfasts than to any other substrata (Fig. 3), despite the general abundance of rock. Only at Millers Point and Glencairn, where the availablility of Pyura stolonifera was high, were significant numbers of kelps growing on these ascidians.

When the density of kelp juveniles is related to available substrata using Jacobs' index of electivity (Fig. 4) a clear pattern emerges. At west coast sites, there is a

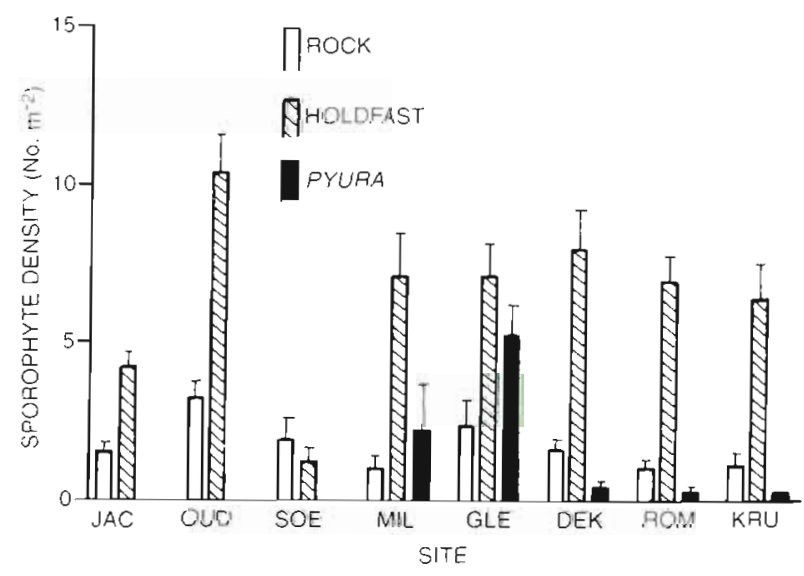

Fig. 3. Ecklonia maxima. Density (+SE) of juvenile sporophytes (up to $0.25 \mathrm{~m}$ ) per area of seabed, on the 3 main substratum types. Site names as in Fig. 2

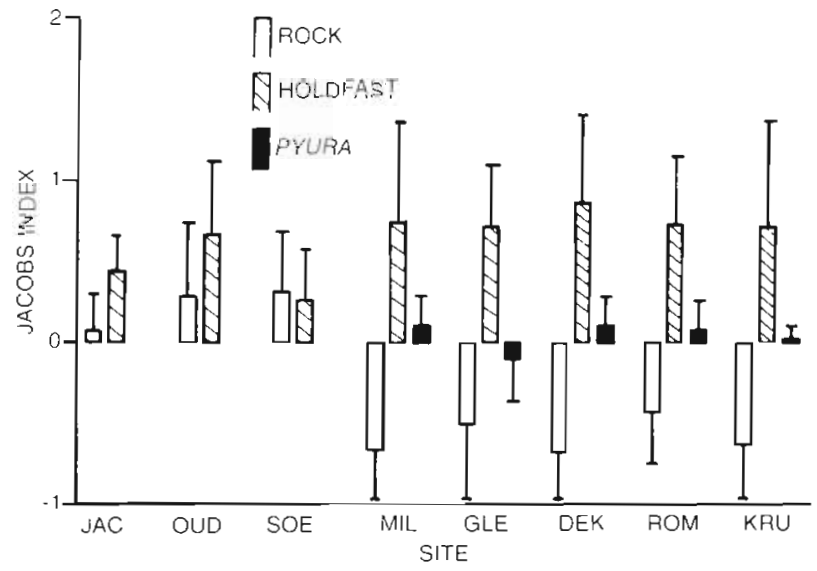

Fig. 4. Ecklonia maxima. Jacobs' index of electivity for densities of kelp juveniles found on the 3 main substratum types (see text for explanation). Vertical lines show $95 \%$ confidence Iimits of means. Site names as in Fig. 2. See Table 1 for results of statistical tests

'positive preference' for holdfasts and rock as substrata, indicating a positive recruitment index. At the transition zone sites the index for rock is strongly negative. This is borne out by statistical comparisons of the results (Table 1). At all the transition zone sites the difference between recruitment indices ('preference') for rock and holdfast is significant. At Jacobsbaai this difference is significant, but the index for holdfasts is positive and that for rock weakly so or neutral. The position of Pyura is neutral.

There were striking differences in the densities of benthic grazers in the transition zone, compared to the west coast sites (Fig. 5). In the transition zone sites, there were 5 genera of grazers. Parechinus angulosus was by far the most abundant, with mean densities of 6 to 28 animals $\mathrm{m}^{-2}$. Patella spp. were the next most

Table 1. Jacobs' index of electivity: results of ANOVA and Tukey HSD test carried out on the data presented in Fig. 4, comparing juvenile kelp densities on 3 substrata at each site, and for all sites combined. Different letters (within each line) denote differences at the $95 \%$ confidence level, and the same letters denote no statistical difference (see 'Materials and methods' for details)

\begin{tabular}{|lccc|}
\hline Site & Rock & $\begin{array}{c}\text { Substrata } \\
\text { Holdfast }\end{array}$ & Pyura \\
\hline Jacobsbaai & A & B & \\
Oudekraal & A & A & \\
Soetwater & A & A & C \\
Millers Point & A & B & A \\
Glencairn & A & B & C \\
De Kelders & A & B & A \\
Romans Bay & A & B & AB \\
Kruismansbaai & A & B & C \\
All sites & A & B & \\
\hline
\end{tabular}




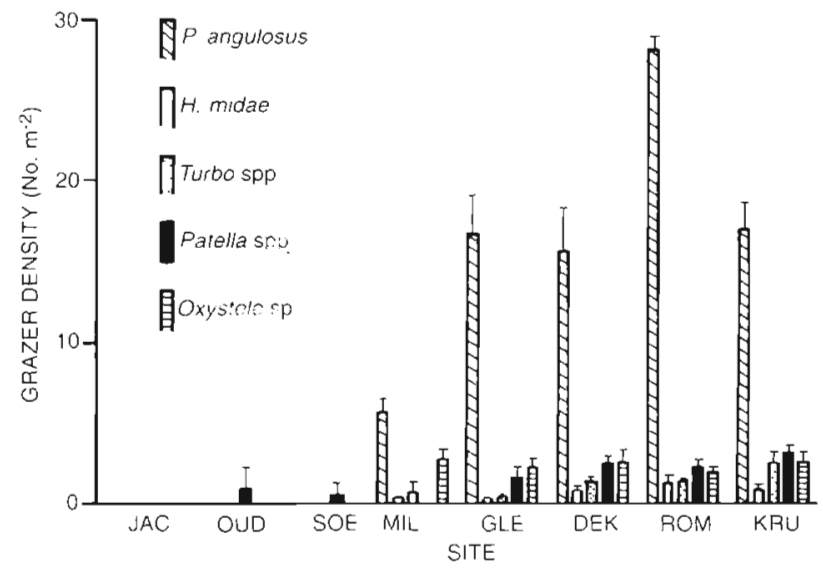

Fig. 5. Density (+SE) of benthic macrograzers at the 8 study sites. Site names as in Fig. 2

abundant, followed by Oxystele sinensis, then Turbo cidaris (and the occasional $T$. sarmaticus), and the abalone Haliotis midae. The only benthic macroherbivores found in the plots at the west coast sites were a few patellid limpets.

There was a direct relationship between the juvenile kelps on holdfast/juvenile kelps on rock ratio and the density of grazers, for the 8 sites (Fig. 6). The mean percentage cover of understorey algae was inversely related to the density of grazers at the 8 sites (Fig. 7) At Romans Bay, where Parechinus angulosus densities may exceed 40 animals $\mathrm{m}^{-2}$, there were 27 to 38 times more young sporophytes on holdfasts than on rock, per unit available area.

In an attempt to generalise about differences between shallow subtidal communities on the west coast and those in the transition zone, we analysed data from the appendices in Field et al. (1980) for 5

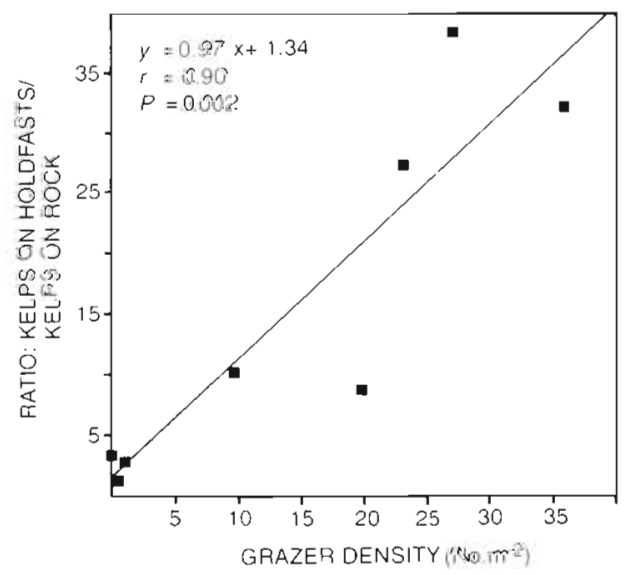

Fig. 6. Ecklonia maxima. Ratio of juvenile kelps on holdfasts/juvenile kelps on rock regressed against the mean density of benthic macrograzers at the 8 study sites

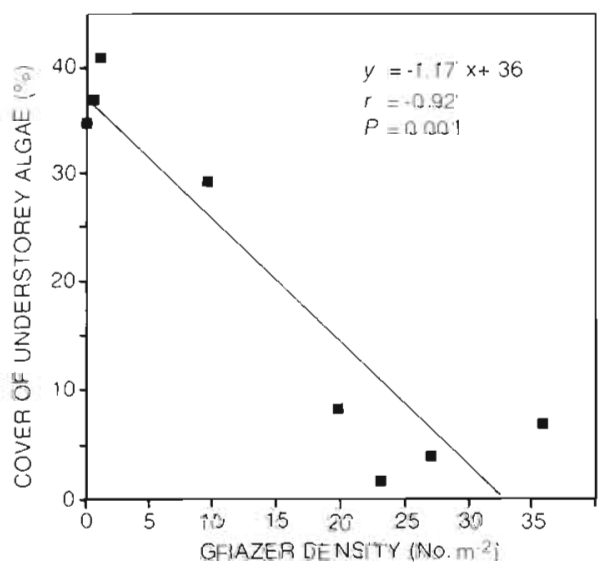

Fig. 7. Mean percentage cover of understorey algae regressed against the mean density of benthic macrograzers at the 8 study sites

west coast and 1 transition zone site and data (G. J. Levitt unpubl.) from Romans Bay and Kruismansbaai. We tested for differences between these 5 west coast and 3 transition zone sites (listed under Fig. 8) with respect to total biomass of benthic macroherbivores, biomass of sea urchins, and biomass of abalone. None were significant. However, when the biomass of grazers from these sites is plotted against the understorey algal biomass, a classic 'log dose/effect' curve is obtained (Fig. 8). We inserted a vertical broken line (no statistical significance) to separate the transition zone

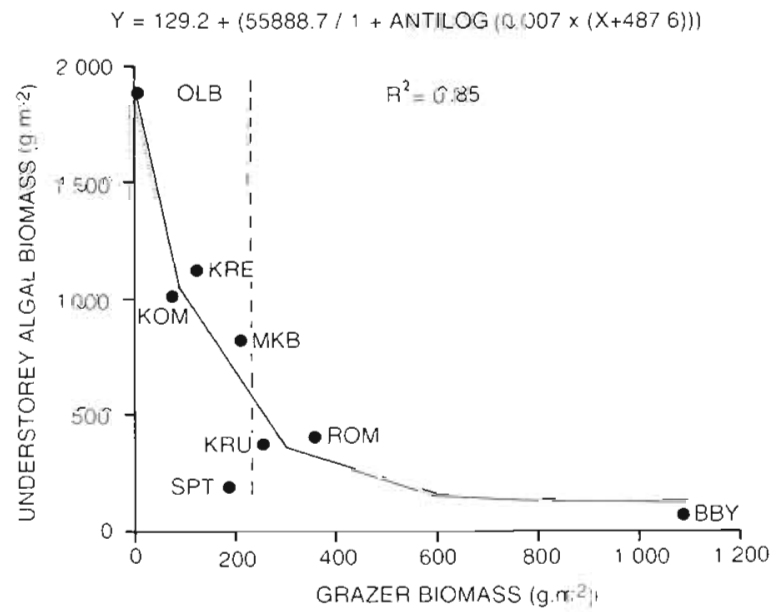

Fig. 8. Relationship between biomass of understorey algae and biomass of benthic grazers at 8 sites in kelp beds of the south-western coast of South Africa. Vertical broken line separates west coast sites (on left) from south/west coast transition zone sites. Data calculated from Field et al. (1980) for sites OLB (Olifantsbos), KRE (Kreeftebaai), KOM (Kommetjie), MKB (Melkbos), SPT (Sea Point) and BBY (Bettys Bay). Data for KRU (Kruismansbaai) and ROM (Romans Bay) from Levitt (unpubl.) 
sites (on the right) from the west coast sites (on the left). These results indicate a broadly inverse relationship between. understorey algal biomass and the biomass of these benthic grazers.

\section{DISCUSSION}

Holdfasts of large kelp plants bore a disproportionately high density of juvenile kelps, compared to rock and Pyura stolonifera. At all of the transition zone sites, where benthic grazers were numerous, juvenile kelp sporophytes showed a statistically significant 'negative selection' of rock, and 'positive selection' of holdfasts as substrata. This was borne out by the significant positive correlation between the ratio of sporophytes on holdfasts/sporophytes on rock and grazer densities (Fig. 6). Although the evidence is correlative, it supports the hypothesis that in heavily grazed areas the recruitment of kelp is strongly limited to holdfasts of large kelps. We measured up to 38 times higher rates of recruitment on holdfasts than on rock, where grazers were abundant. In such areas juvenile kelps are rare on rock, and tend to be restricted to crevices or pinnacles, where they are likely to be less accessible to grazers. Although we expected that the cylindrical tests of $P$. stolonifera would be an important refuge for kelp juveniles, this proved not to be the case, and they were 'neutrally' selected for. Further evidence that holdfasts are important refuges comes from a subsequent study which found that in a grazer-free area (Oudekraal), $75 \%$ of adult Ecklonia maxima clearly arose from single-stiped holdfasts, while at 3 sites with numerous grazers, this value fell to $45 \%$ (West \& Anderson unpubl.).

Holdfasts of adult Ecklonia maxima plants are shallowly conical in shape and about $100 \mathrm{~mm}$ high at the apex (where the stipe originates). Single holdfasts may be $150 \mathrm{~mm}$ or more in diameter, whilst composite holdfasts, with several stipes, are larger. Holdfasts comprise a mass of intertwined haptera which become progressively thinner as they branch towards the substratum, with crevices and hollows between the haptera. Their effectiveness as refuges will depend on the size of crevices, herbivores, and sporelings. In addition, benthic grazers are probably easily dislodged from holdfasts, which provide an irregular surface for attachment. Haliotis midae was never seen on holdfasts, and Parechinus angulosus and Turbo cidaris were only found there during the calmest swell conditions, when they sometimes graze the haptera.

Various kelps recruit on a variety of 'temporary' substrata such as worm tubes and small algae, but their survival depends on attaching to the primary substratum (Dayton 1985). Small Ecklonia maxima sporo- phytes can be found on corals, mollusc shells, and seaweeds such as geniculate corallines. However, unless their positively geotropic haptera reach a firmer substratum, they are likely to be torn off as they grow larger.

We assume that the recruitment we are measuring represents the sum of survival, on all available substrata, of all stages subsequent to the 'spore rain' (Chapman 1984), including the newly settled spores, the microscopic gametophytes and the young sporophytes. Demographic and recruitment studies indicate that mortality is highest among microscopic stages, followed by young sporophytes (e.g. Chapman 1984, Deysher \& Dean 1986, Dayton et al. 1992). Survival of different stages is influenced by a variety of herbivores, from meoifauna to abalone, urchins and fish (Dayton 1985). According to Branch et al. (1994) microscopic algae and spores form the bulk of the diets of Oxystele and Patella spp., while Haliotis midae, Turbo spp. and Parechinus angulosus eat algal sporelings, drift and attached seaweeds (including small kelps): we have frequently seen them eat small sporophytes when the sea is very calm. It is likely that the vulnerability of kelp sporophytes to these benthic grazers decreases as their stipes grow. Their effect on understorey algae is shown by the negative correlation between percentage cover of understorey algae and grazer densities (Fig 7). We cannot rule out the possibility that hydrodynamic factors influence the sites that kelp spores (and thus gametophytes and ultimately sporophytes) settle on, as has been shown in some invertebrate larvae (Walters \& Wethey 1996), but we do not know to what extent the motile Ecklonia maxima zoospores are capable of selecting a settlement site.

Parechinus angulosus is by far the most numerically abundant grazer in the shallow water ( 2 to $5 \mathrm{~m}$ ) of transition zone kelp beds (Fig. 5). On the west coast it is generally uncommon in shallow water, but found in occasional but dense patches in deeper water ( 8 to 15 m), where it produces isolated barren areas of rock, from a few metres to tens of metres in diameter (Velimirov et al. 1977. Field et al. 1980). Buxton \& Field (1983) estimated that $P$. angulosus consumed $14 \%$ of the annual production of Ecklonia maxima (mainly as drift) at Oudekraal on the west coast, while Fricke (1979) estimated a figure of $20 \%$ at Miller's Point in False Bay, and pointed out that grazing by $P$. angulosus appeared to regulate kelp densities to some extent. We suggest that $P$. angulosus has a greater effect than other grazers because it is more numerous and has a higher total biomass. Haliotis midae are much larger but far less numerous, and Turbo cidaris are a similar size to urchins, but less abundant. Patella spp. and Oxystele spp., are both less numerous and individually 
smaller. Nevertheless, it is possible that $P$. angulosus is not the most functionally important grazer, and these animals may be affecting recruitment as a suite. Selective removals of the different species could test these ideas.

Factors which have been shown to inhibit kelp recruitment include the presence of red algae (northwest America; Sousa 1979), the presence of turf algae or a kelp canopy (Australia; Kennelly 1987), shedding of outer layers by coralline algae (Chile: Camus 1994) and adult interference and grazing by herbivores (in the Lessonia/Durvillea belt in central Chile), where recruitment fails if adult densities exceed $3 \mathrm{~m}^{-2}$ (Santelices 1990).

The phenomenon of facilitation of one species by another is well known in terrestrial ecology (Connell \& Slatyer 1977). In a Californian kelp community, fastgrowing brown algae colonised disturbed patches of reef, and facilitated the recruitment of kelps by providing a refuge from grazing fish (Harris et al. 1984). In Chile the intertidal kelp Lessonia nigrescens was shown by Camus (1994) to recruit effectively on Corallina officinalis, which provides a refuge from grazing by chitons. In the present study the enhanced densities of young sporophytes on the holdfasts of older plants show that self-facilitation is occurring in Ecklonia maxima. Velimirov \& Griffiths (1979) described another of example of self-facilitation in the sweeping of the fronds of the deeper-water South African kelp Laminaria pallida. Once a few adults become established, their fronds, which are on the ends of the erect stipes, sweep the surrounding rock and prevent the establishment of other macro-organisms. New sporophytes establish under the adults, and so the patch of Laminaria slowly spreads. Adult E. maxima do not sweep the substratum, because the buoyant bladder at the top of the stipe suspends the fronds near the water surface. However, in both $L$. pallida and E. maxima, once a few sporophytes become established, survival is maximised closest to parent plants. Spore dispersal in kelps (Laminariales) is considered to occur only over short distances (Schiel \& Foster 1986, Santelices 1990). This may have several advantages, including increasing the chance of fertilisation between dioecious gametophytes, and retaining spores within a localised habitat which is suitable for growth (Norton 1992). In E. maxima this may also serve to ensure recruitment on the holdfasts of adults, providing protection against herbivores.

If Ecklonia maxima sporophytes and their holdfasts were cleared from an area with numerous benthic grazers, the lack of refugia should prevent or delay recolonisation. Whether this could lead to the 'alternative stable state' of an extensive 'urchin barren' similar to those reported in some northern hemisphere kelp beds
(Harrold \& Reed 1985, Chapman \& Johnson 1990) is not clear. The term 'barrens' as applied to South African kelp beds (Field \& Griffiths 1991) is misleading, as these are no more than small, isolated patches of Parechinus angulosus, usually about 10 to $20 \mathrm{~m}$ in diameter, and limited to deeper water, invariably on the west coast. The absence of extensive urchin barrens in South African kelp beds, even in the transition zone where $P$. angulosus is very numerous, may relate to the behaviour of $P$. angulosus, which, unlike Strongylocentrotus, does not form feeding fronts, so that a mosaic of subtidal communities is maintained. Also, swells may be too strong for $P$. angulosus to form large aggregates in shallow water (down to 5 or $6 \mathrm{~m}$ ), which would explain why the small aggregates that do occur are almost invariably limited to deeper water (8 to $15 \mathrm{~m}$ ). Also, $P$. angulosus does not appear to destroy adult kelps, so that an alternative state would have to be induced by an external disturbance such as extreme storm damage or overharvesting.

On the North American Pacific coast, the development of an urchin-dominated alternative stable state is often triggered by storms removing kelp canopies (Dayton \& Tegner 1984, Harris et al. 1984), and the resulting barren grounds may account for up to $20 \%$ of kelp habitats (Foster 1990). This does not occur in South African kelp beds, although they may be thinned out by storms. This difference may result from the morphology of Ecklonia maxima, which has a relatively short, thick smooth stipe (compared to Macrocystis), with far less potential for entangling with and removing other plants.

Whether an alternative stable state (barren) could be induced in the South African transition zone, by overharvesting of adult kelps, is debatable. Nevertheless, our results predict that recruitment will be limited or delayed where benthic grazers are numerous: this is borne out by current kelp-harvesting experiments. At Soetwater and Jacobsbaai (west coast sites), recovery of the kelp canopy takes about 2.5 yr after harvesting of all kelps (almost entirely Ecklonia maxima) by cutting of stipes longer than $0.5 \mathrm{~m}$. At Romans Bay and Kruismansbaai (transition zone sites), recruitment was severely delayed after similar harvesting, and after $3 \mathrm{yr}$ there were still large gaps in harvested lanes (G. J. Levitt unpubl.). The numerous grazers (mainly urchins) not only severely limited recruitment on rock, but more important, the holdfasts of cut kelps rotted of the substratum within 4 to 6 mo, taking with them any small kelp sporophytes which were not also firmly attached to rock. Where there are few grazers and thus many small sporophytes on rock (typical of the west coast), the loss of holdfasts is not as serious, and rapid growth of these juveniles soon replaces the canopy. Our results suggest that if the major benthic grazers were 
experimentally removed from areas such as Romans Bay, there would be a significant increase in kelp recruitment and understorey algal cover. Such urchin removals at Cape Banks, Australia, resulted in large increases in algal recruitment, growth and survival (Fletcher 1987).

Benthic understorey communities in shallow south/ west coast transition zone kelp beds are different from those on the west coast, in terms of both seaweed biogeography (Bolton 1986) and densities of benthic grazers, especially Parechinus angulosus, as shown by diving observations and present results (Fig. 8). There are exceptional sites, such as Sea Point, which, of the 5 west coast sites cited by Field et al. (1980), was the only one with high densities of $P$. angulosus. These authors examined only 1 transition zone site (Betty's Bay) and noted that the herbivore biomass was very high, but from 1 site were unable to generalise about this zone.

There are other important differences between these coasts. On the west coast, recruitment of abalone is poor (R. Tarr pers. comm.) and rock lobsters Jasus lalandii are abundant (Field et al. 1980). Recently, increases in rock lobster abundance in parts of the transition zone have coincided with decreases in Parechinus angulosus (a favoured prey) and in juvenile abalone, which shelter under the urchins (Tarr et al. 1996). We predict that kelp recruitment and the cover of understorey algae will increase. In this system the rock lobsters are clearly a keystone species, as they are capable of causing a 'trophic cascade' effect (Menge et al. 1994)

The environmental reasons for biological differences between the transition zone and the west coast may be at least partly related to the average 2 or $3^{\circ} \mathrm{C}$ higher water temperature in the transition zone (Bolton 1986. Bolton \& Anderson 1990). These authors explained phytogeographical differences between the zones on this basis, because the geographical distributions of seaweeds along continuous coastlines are almost completely controlled by temperature (Breeman 1988). However, patterns of abundance (rather than presence or absence) are not as easily explained. For example, temperatures in the transition zone are close to optimal for growth and reproduction of the gametophyte and growth of the young sporophyte of Ecklonia maxima, as measured in laboratory studies (Bolton \& Levitt 1985, Bolton \& Anderson 1987). Whatever the environmental causes, the present study suggests for the first time that there are fundamental differences between ecological processes in the kelp beds of the west coast and the transition zone that have important implications both for biological understanding and for the harvesting and management of commercial resource species such as E. maxima, abalone and rock lobsters
Acknowledgements. We thank Derek Kemp, Chris Boothroyd, Geoff Fridjhon and Alan Ellis for diving assistance This study was supported by the Director, Sea Fisheries Research Institute.

\section{LITERATURE CITED}

Anderson RJ, Simons RH, Jarman NG (1989) Commercial seaweeds in southern Africa: a review of utilization and research. S Afr J Mar Sci 8:277-299

Bolton JJ (1986) Marine phytogeography of the Benguela upwelling region on the west coast of southern Africa: a temperature dependent approach. Bot Mar 29:251-156

Bolton JJ, Anderson RJ (1987) Temperature tolerances of two southern African Ecklonia species (Alariaceae: Laminariales) and of hybrids between them. Mar Biol 95:293-297

Bolton JJ, Anderson RJ (1990) Correlation between intertidal seaweed community composition and sea water temperatures on a geographical scale. Bot Mar 33:447-457

Bolton JJ, Levitt GJ (1985) Light and temperature requirements for growth and reproduction in gametophytes of Ecklonia maxima (Alariaceae: Laminariales). Mar Biol 87 : $131-135$

Branch GM, Griffiths CL, Branch ML, Beckley LE (1994) Two oceans: a guide to the marine life of southern Africa. David Philip, Cape Town

Breeman AM (1988) Relative importance of temperature and other factors in determining geographic boundaries of seaweeds: experimental and phenological evidence. Helgoländer Meeresunters 42:199-241

Buxton C. Field JG (1983) Feeding, defaecation and absorption efficiency in the sea urchin, Parechinus angulosus Leske. S Afr J Zool 18:11-14

Camus PA (1994) Recruitment of intertidal kelp Lessonia nigrescens Bory in northern Chile: successional constraints and opportunities. J Exp Mar Biol Ecol 184:171-181

Chapman ARO (1984) Reproduction, recruitment and mortality in two species of Lammaria in southwest Nova Scotia. J Exp Mar Biol Ecol 78:99-109

Chapman ARO, Johnson CR (1990) Disturbance and organization of macroalgal assemblages in the Northwest Atlantic. Hydrobiologia 192:77-121

Connell JH, Slatyer RO (1977) Mechanisms of succession in natural communities and their role in community stability and organisation. Am Nat 111:1119-1144

Dayton PK (1985) Ecology of kelp communities. Annu Rev Ecol Syst 16:215-24.5

Dayton PK, Tegner MJ (1984) Catastrophic storms, El Niño, and patch stability in a California kelp community. Science 224:283-285

Dayton PK, Tegner MJ, Parnell FE, Edwards PB (1992) Temporal and spatial patterns of disturbance and recovery in a kelp forest community. Ecol Monogr 62:421-445

Deysher LE, Dean TA. (1986) In situ recruitment of the giant kelp. Macrocystis pyrifera: effects of physıcal factors. J Exp Mar Biol Ecol 103:41-63

Field JG, Griffiths CL (1991) Littoral and sublittoral ecosystems of southern Africa. In: Mathieson AC, Nienhuis PH (eds) Ecosystems of the world 24. Intertidal and littoral ecosystems. Elsevier, Amsterdam, p 323-346

Field JG, Griffiths CL, Griffiths RJ, Jarman N, Zoutendyk P, Velimiriv B, Bowes A (1980) Variation in structure and biomass of kelp communities along the south-west Cape coast. Trans R Soc S Afr 44:145-203

Fletcher WJ (1987) Interactions among subtidal Australian sea urchins, gastropods and algae: effects of experimental 
removals. Ecol Monogr 57:89-109

Foster MS (1990) Organization of macroalgal assemblages in the northeast Pacific: the assumption of homogeneity and the illusion of generality. Hydrobiologia 192:21-23

Fricke AH (1979) Kelp grazing by the common sea urchin Parechinus angulosus Leske in False Bay. Cape. S Afr J Zool 14:143-148

Harris LG, Ebelıng AW, Laur DR, Rowley RJ (1984) Community recovery after storm damage: a case of facilitation in primary succession. Science 224:1336-1338

Harrold RC, Reed DC (1985) Food availability, sea urchin grazing, and kelp forest community structure. Ecology 66:1160-1169

Jacobs J (1974) Quantitative measurement of food selection: a modification of the Forage Ratio and Ivlev's Selectivity Index. Oecologia 14:413-417

Kennelly SJ (1987) Inhibition of kelp recruitment by turfing algae and consequences for an Australian kelp community. J Exp Mar Biol Ecol 112:49-60

Menge BA, Berlow EL, Blanchette CA (1994) The keystone species concept: variation in interaction strength in a rocky intertidal habitat. Ecol Monogr 64:249-286

Newell RC, Field JG, Griffiths CL (1982) Energy balance and significance of micro-organisms in a kelp bed community. Mar Ecol Prog Ser 8:103-113

Norton TA (1992) Dispersal by macroalgae. Br Phycol J 27 : 293-301

Editorial responsibility: Otto Kinne (Editor), Oldendorf/Luhe, Germany
Santelices B (1990) Patterns of organizations of intertidal and shallow subtidal vegetation in wave exposed habitats of central Chile. Hydrobiologia 192:35-57

Schiel DR, Foster MS (1986) The structure of subtıdal algal stands in temperate waters. Oceanogr Mar Biol Annu Rev 24:265-307

Sousa WP (1979) Experimental investigations of disturbance and ecological succession in a rocky intertidal algal community. Ecol Monogr 49:227-254

Tarr RJQ, WIllams PVG, Mackenzie AJ (1996) Abalone, sea urchins and rock lobster: a possible ecological shift that may affect traditional fisheries. S Afr J MIar Sci 17:319-323

Velimisov B, Field JG, Griffiths CL, Loutendyk P (1977) The ecology of kelp bed communities in the Benguela upwelling system. Helgoländer Wiss Meeresunters 30: 495-518

Velimirov B, Griffiths CL (1979) Wave-induced kelp movement and its importance for community structure. Bot Mar 22:169-172

Walters LJ, Wethey DS (1996) Settlement and early postsettlement survival of sessile marine invertebrates on topographically complex surfaces: the importance of refuge dimensions and adult morphology. Mar Ecol Prog Ser 137:161-171

Wilkins HKA, Myers AA (1992) Microhabitat utilısation by an assemblage of temperate Gobiidae (Pisces: Teleostii). Mar Ecol Prog Ser 90:103-112

Submitted: April 3, 1997; Accepted: September 27, 1997 Proofs received from author(s): November 21, 1997 